\title{
Diesel Particulate Matter Issues in Indonesia Underground Mining Industry
}

\author{
Darius Agung Prata ${ }^{1,2}$, Indri H. Susilowati ${ }^{1}$, and Dewi Susanna ${ }^{1}$ \\ ${ }^{1}$ Faculty of Public Health, Universitas Indonesia, Depok, Indonesia \\ ${ }^{2}$ Education and Training Unit for Underground Mine
}

\section{Abstract}

One of the most critical technology for the underground mining industry is a diesel engine. Beside an advantage, the diesel engine has disadvantaged due to gas and particulate emission called diesel particulate matter (DPM). In this paper, we described DPM issues all over the world and potential risk exposure in Indonesia underground mining industry.

To have an understanding of the issues all over the world, this research was performed by reviewing paper from journal, proceedings, textbook, report, also compare with regulation, guidance, and standard on DPM topic. To analyze DPM risk emitted by diesel

Corresponding Author: Darius Agung Prata dariusagung@gmail.com

Received: 26 December 2018 Accepted: 23 February 2019 Published: 7 March 2019

Publishing services provided by Knowledge E

(c) Darius Agung Prata et al. This article is distributed under the terms of the

Attribution License, which permits unrestricted use and redistribution provided that the original author and source are credited.

Selection and Peer-review unde the responsibility of the $2 \mathrm{nd}$ International Meeting of Public Health 2016 Conference Committee.

\section{G OPEN ACCESS} engines, a questionnaire was sent by mail to seven underground mining companies in all around Indonesia.

There was a potential risk for underground mining worker in Indonesia to become exposed by DPM based on data analysis. There were four respondents using diesel engines in their operation with the highest population of diesel engines 717 unit for High Duty Vehicle and 380 unit for Light duty vehicle. Another research study to assess correct emission rate in several underground mines with more comprehensive parameter must be conducted to support the government of Indonesia with more reliable data to publish regulation on DPM.

Keywords: diesel particulate matter; risk; underground mining

\section{Introduction}

Diesel engines are very accessible technology for many industries and also widely used in underground mining because of its efficiency, versatility, reliability, and durability (Burgasky, 2012). Besides advantages, diesel engines have disadvantages due to gas and substantial emission also known as diesel particulate matter (DPM). Diesel engines produce a different discharge in solid and gas phase (Talla, 2012). Carbon monoxide (lower than gasoline engines), nitrogen dioxide and volatile organic compound like benzene and formaldehyde are in the gas phase while elemental and organic carbon, ash, sulfate, and metals are in the solid phase. Polycyclic aromatic hydrocarbons and nitroarenes 
distribute over the gas and the particle phase. DPM concentration is six to ten times higher than the petrol engine (Resitoglu, 2015).

Pollutant emissions have a rate of less than $1 \%$ in the diesel exhaust gas (Resitoglu, 2015). Nitrogen Oxide (NOx) has the most substantial proportion of diesel pollutant emissions with a balance of more than 50 \% (Resitoglu, 2015). After NOx emissions, PM has the second largest percentage of pollutant emissions. Because diesel engines are lean combustion engines, the concentration of $\mathrm{CO}$ and $\mathrm{HC}$ is minimal (Resitoglu, 2014). DPM has more attention since declaring as a group 2A category "probably carcinogenic to humans" by WHO on 1988. Twenty-four years later, it has been becoming to group 1 "carcinogenic to human" (WHO, 2012).

Nowadays there is no regulation or standard on DPM in Indonesia mining industry. Diesel emission regulations from the government of Indonesia only are arranged to protect underground mine worker from diesel emission for $\mathrm{CO}$ and NOx gas (Kepmen PE No 555.MPe/1995 article 387.5). There are 15 underground coal mines and seven underground non-coal mines operating today in Indonesia. Underground coal mining does not use diesel engines in their operation on the mine tunnel while on the non-coal mining, almost all drilling use diesel engines in their process. Because of the hazard from DPM as a carcinogenic material to human, it is essential to understand DPM risk in Indonesia underground mining industry.

\section{Methods}

To have an understanding about DPM issues all over the world, this research was performed by reviewing paper from ten journals, two proceedings, one textbook, four reports, and also looked at one legislation, one guidance and one standard published on DPM topic.

To analyze DPM risk emitted by diesel engines, it was conducted by sending a questionnaire to six underground mining company all around Indonesia.

\section{Results}

Based on the review of relevant material on several kinds of literature and the survey, the DPM issues will be described below. 


\subsection{Diesel particulate matter (DPM) properties}

Diesel particulate matter is a submicrometer aerosol emitted by diesel engines. DPM is considered to be a product of incomplete combustion of fuel and lubricant hydrocarbons. The chemical, physical, and toxicological properties of DPM depend on many parameters. The parameters are engine design, engine operating conditions, fuel, and lubricating oil properties, exhaust after treatment, environmental conditions, also engine age (Burgasky, 2012).

Mined materials by drilling, blasting, grinding, crushing, handling, and transportation operations are the primary source of respirable dust containing coarse particles with an aerodynamic diameter of roughly one $\mu \mathrm{m}$ and ten $\mu \mathrm{m}$ (Burgasky, 2012). Diesel engines are the primary source of submicrometer aerosols (aerosols composed of particles that are less than one $\mu \mathrm{m}$ in diameter) in underground mines that using diesel-powered equipment (Cantrell et al, 1991). Underground miners are the highest suspect among workers in all occupations to become exposure by DPM (Cohen et al, 2002 \& Pronk et al, 2009). The DPM exposure rates of underground miners are higher than railroad workers and truck drivers (Cohen et al, 2002).

DPM produced by diesel engine combustion have a variance on size diameter, but generally on submicron-diameter. There are three mode on DPM emitted by the diesel engine : nucleation mode, accumulation mode and coarse mode (Whitby\&Cantrell, 1976). To have a better understanding of DPM diameter, it can be seen in Figure 1. Based on the illustration, it shows that the DPM position has a significant number below $0.01 \mu \mathrm{m}$. Because of its size diameter, DPM can enter the blood vessel through tissue organ in human pulmonary (Glyn, 2012).

\subsection{DPM health effect}

DPM can result in acute and chronic health effects depending on the dosage and length of exposure (Evan, 2015). Dangerous effects can cause severe irritation, neurophysiological symptoms, respiratory symptom, immunologic effect the exacerbation of allergenic response to known allergens and asthma-like symptom (EPA, 2002). Chronic health effects are divided into non-cancer and carcinogenic. Noncancer outcome based on human research is inadequate to judge health effects on human. However, based on the research study to an animal, DPM shows a spectrum of dose-dependent inflammation and histopathological changes in the lung in several animal species including rats, mice, hamsters, and monkeys (EPA, 2002). 


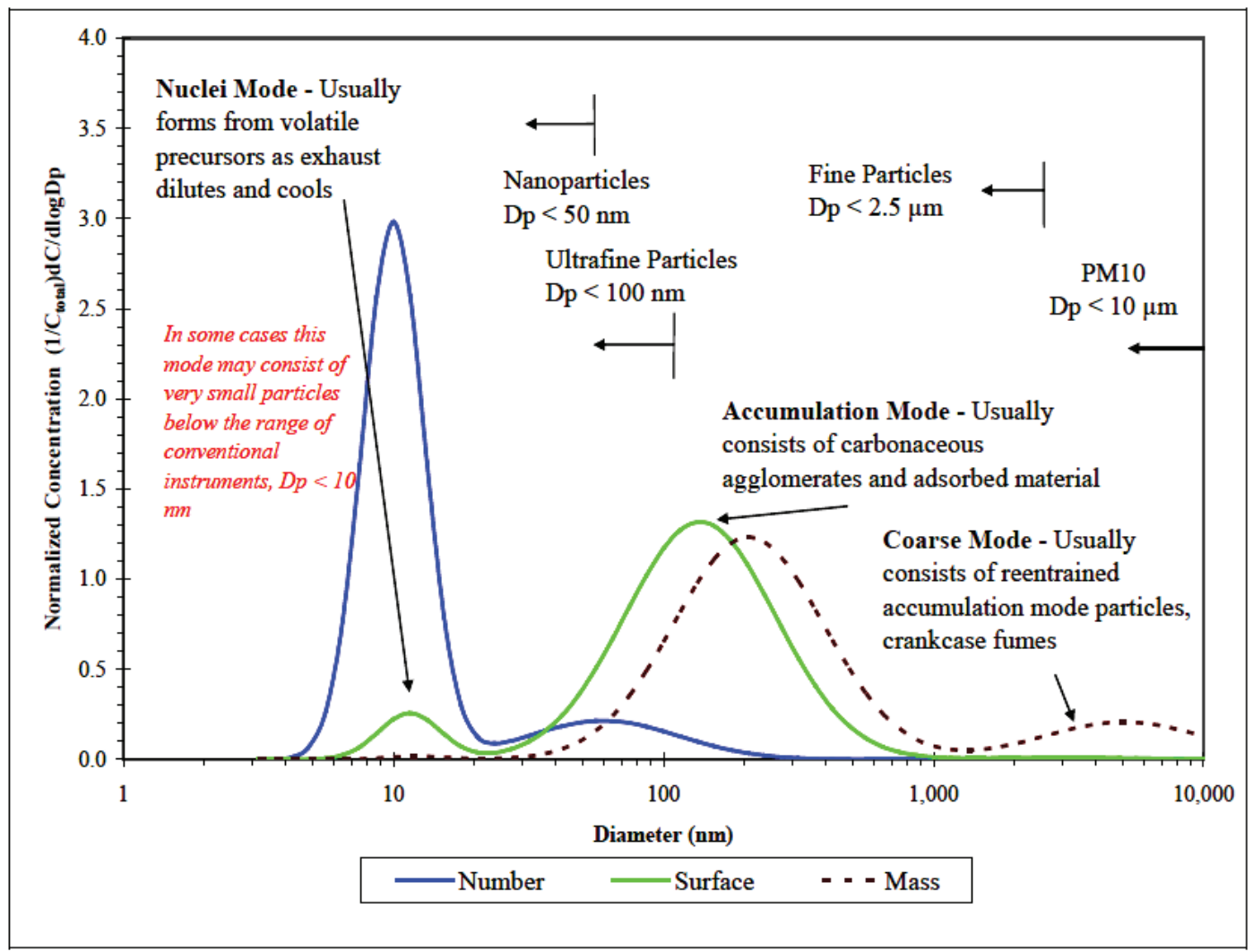

Figure 1: DPM Mode (Source: Kittelson (2014)).

Nowadays, based on many research studies, there is possible correlation DPM exposure and lung cancer as a chronic effect (Villeneuve, 2011 \& WHO, 2012). The research study by Vermeulen et all in 2014 analyzed that three different epidemiology studies showed that at least $6 \%$ death case per year was caused by DPM exposure. Because of its dangerous, DPM was declared as a group 1 category "carcinogenic to human" by WHO on 2012.

\subsection{DPM standard}

Several countries published guidance to limit DPM exposure in the working environment to protect the worker from DPM health hazard outcome (Table 1).

Diesel engine emission standard was also published both in Europe and America. Today, Euro Standard implemented $0.01 \mathrm{~g} / \mathrm{kWh}$ for particulate on Euro 6 category for Bus and truck while in America, EPA Tier $4 \mathrm{f}$ reduced the number of particulate to 0.01 g/hp-from 0.4 g/hp-hr on tier 1 in 1996.

The current DPM exposure standards were not establish as health-based standards, but feasibility standards. Lack of defined universal dose -responses relationship for complex aerosols prevented creating health-based exposure level (Burgasky, 2014). As 
TABLE 1: DPM Standard Number in Several Country (Source: Burgasky (2014)).

Country
USA
Canada
- Ontario
- Quebec
- Other
Germany
- Tunneling and non-coal mining
- Other than tunneling and non-coal mining
- Other than tunneling and non-coal mining
when OC>EC
Australia
(New South Wales, Queensland, Western
Australia)

limiting number
$160 \mu \mathrm{g}_{\mathrm{Tc}} / \mathrm{m}^{3}$
$400 \mu \mathrm{g} / \mathrm{m}^{3}$ of TC (or $1.3^{*} \mathrm{EC}$ )
$600 \mu \mathrm{g} / \mathrm{m}^{3}$ of TC
$\mathrm{MSHA}$ or $1500 \mu \mathrm{g} / \mathrm{m}^{3}$
$300 \mu \mathrm{g} / \mathrm{m}^{3}$ of EC
$100 \mu \mathrm{g} / \mathrm{m}^{3}$ of EC
$150 \mu \mathrm{g} / \mathrm{m}^{3}$ of TC
$100 \mu \mathrm{g} / \mathrm{m}^{3}$ of submicron EC

a reference, the excess lifetime risk (XLTR) of exposure to $0.8 \mu \mathrm{g} / \mathrm{m}^{3}$ (ambient) was estimated to be 21 additional lung cancer deaths per 10.000 individuals as compared to an unexposed population (Vermeulen et al. 2014).

Understanding diesel emission on everyday performances in underground mining is important to understand how many DPM emitted from diesel engines operation. DPM emission rate based on daily performance could be understood based on the research report by Rubelli and Gangal (2003) in Canada. The data in Table 2 was modified to have an emission rate summarize to become two categories, high duty vehicle (HDV) and low duty vehicle (LDV).

TABLE 2: DPM Emission Rate (Source: Rubelli and Gangal (2003)).

\section{Category}

High Duty Vehicle

Light duty vehicle
DPM Emission Rate (gr/hr)

19.31

7.32

The best controlling technics to reduce hazard came from the source. In the last 30 year, diesel engines modification made rapid progress to minimize particulate and nitrogen oxide emission (Fiebig, 2014). Several technologies were invented to control diesel engine emission besides combustion efficiency of the engine and fuel selection. There was a view of an emission control device that could be possible to reduce DPM emission. The device technology was the particulate filter, catalytic converter, scrubber, acoustic agglomeration also cyclone (Gov of Western Australia, 2013). The particulate filter and catalytic converter could reduce by nearly $100 \%$ of a particle (Fiebig, 2014). 


\subsection{Diesel engine operation in several underground mine in Indonesia}

All of 7 non-coal mining company were targeted as a respondent for the research. There were five mining companies sending feedback to participating as a respondent. The result of the diesel engine number and emission rate estimated was shown in Table 3 below.

TABLE 3: DPM Emission Rate In Indonesia.

\begin{tabular}{|l|c|c|c|}
\hline Respondent & \multicolumn{2}{|c|}{ Number of diesel engine } & $\begin{array}{c}\text { DPM Emission Rate } \\
\text { (estimated) } \mathbf{( g / h r )}\end{array}$ \\
\hline & HDV & LDV & \\
\hline 1 & 717 & 380 & 16.627 \\
\hline 2 & 5 & 7 & 148 \\
\hline 3 & 3 & 2 & 73 \\
\hline 4 & 8 & 0 & 155 \\
\hline 5 & 0 & 0 & 0 \\
\hline
\end{tabular}

The DPM emission rate estimation was calculated from the number of the diesel engine in the underground mining company with diesel emission rate in Table 2.

\section{Discussions}

The highest diesel engine population came from respondent number 1 with 717 HDV and 308 LDV and was assumed $16.627 \mathrm{~g} / \mathrm{hr}$ DPM emitted to the mine tunnel environment. The lowest diesel engine population came from respondent number 5 with 0 diesel engine operation in the tunnel and also with 0 emission rate. Based on the DPM emission rate estimation, it meant that the higher number of diesel engines service related to emissions rate was increasing. Because of the carcinogenic effect of DPM to the human, Indonesian underground mine workers especially for company respondents 1 to 4 were in the high-risk condition as a lung cancer suspect. The government of Indonesia should concern to monitor DPM emission in the mining environment, because of many evidence today from all over the world leads DPM has a carcinogenic effect on the human lung.

This research was only for the preliminary study to understand the condition of underground mining operation compared to the DPM emission risk in Indonesia. It should be following with another research to assess the correct emission rate in several underground mines with more general parameter including; diesel engine type, fuel, and lubricating oil, exhaust after treatment also working condition to support the government of Indonesia with more reliable data to publish regulation on DPM topic. 


\section{Acknowledgments}

The author would like to acknowledge to the Ministry of Energy and Mineral Resources as a sponsorship for the scholarship and also to the all of the mining companies that became a participant to support the data.

\section{References}

[1] Bugarski, A.D. Janisko, S. Cauda, E.G., Noll, J.D. Mischler, S.E. 2012. Controlling Exposure -Diesel Emissions in Underground Mines. Society for Mining, Metallurgy, and Exploration.

[2] Bugarski, A.D. Stachulak, J. 2014. Diesel Aerosols and Gases in Underground Mines. Workshop material on The Australian Mine Ventilation Conference, Sydnes Australia

[3] Cantrell, B.K. 1987. Source apportionment analysis applied to mine dust aerosols: coal dust and diesel emissions aerosol measurement. In: Mutmansky JM, ed. Proceedings of the 3rd Mine Ventilation Symposium. Littleton, CO: Society for Mining, Metallurgy, and Exploration, pp. 495-501.

[4] Cohen, H.J. Borak, J. Hall, T. Sirianni, G. Chemerynski, S. 2002. Exposure of miners to diesel exhaust particulates in underground nonmetal mines. AlHA J 63: 651-658.

[5] EPA (Environmental Protection Agency). 2002. Health assessment document for diesel engine exhaust. It prepared by the National Center for Environmental Assessment, Washington, DC, for the Office of Transportation and Air Quality; EPA/600/890/057F. Available from: National Technical Information Service, Springfield, VA; PB2002-107661, and <http://www.epa.gov/ncea>.

[6] Evan, D. 2015. An Evaluation Of Carbon Concentrations Associated With Biodiesel Particulate Matter In An Underground Metal Mine. Master of Science In Industrial Hygiene Thesis, Montana Tech University, USA

[7] Fiebig M., Wiartalla A., Holderbaum B., Kiesow S., 2014. Particulate Emissions From Diesel Engines: Correlation Between Engine Technology And Emissions., Journal of Occupational Medicine and Toxicology.

[8] Glynn, P. 2012. Using acoustic agglomeration of diesel particulate to reduce or eliminate diesel particulate emissions. Australian Journal of Mining (January/February)

[9] The government of Western Australia, 2013, "Guideline Management of diesel emissions in Western Australian mining operations."

[10] Haney, R.A. Saseen, G.P. Waytulonis, R.W. 1997. An Overview of Diesel Particulate Exposures and Control Technology in the U.S. Mining Industry, Applied Occupational 
and Environmental Hygiene, 12:12, 1013-1018 http://www.tandfonline.com/doi/abs/10. 1080/1047322X.1997.10390642 (accessed Jan 20, 2017)

[11] Hedges, K. Djukic, F. Irving, G. 2007. Diesel Particulate Matter in Underground MinesControlling the Risk (an Update) Reproduced from the presented paper at 'The AusIMM New Leaders' Conference.

[12] http://www.qldminingsafety.org.au/_dbase_upl/hedgesDiesel\%20Particulate\% 20Matter\%20in\%20Underground\%20Mines.pdf (accessed Jan 20, 2017)

[13] Kittelson, D. and Kraft, M. 2014. Particle Formation and Models in Internal Combustion Engines. Technical Report Cambridge Centre for Computational Chemical Engineering, University of Cambridge

[14] McDonald, J.D. Zielinska, B. Sagebiel, J.C. McDaniel, M.R. Mousset-Jones, P. 2003. Source apportionment of airborne fine particulate matter in an underground mine. $J$ Air Waste Manage Assoc 53: 386-395.

[15] Pronk, A. Coble, J. Stewart, P.A. 2009. Occupational exposure to diesel engine exhaust: a literature review. J Exposure Sci Environ Epidemiol 19: 443-457.

[16] Resistol, I.A. Altinisk, K. Keskin, A. 2015. The pollutant emissions from diesel-engine vehicles and exhaust after-treatment systems. Clean Techn Environ Policy (2015) 17:15-27

[17] Rubeli, B. Gangal, M. Butler, K. Aldred, W. 2003. Evaluation Of The Contribution Of Light-Duty Vehicles To The Underground Atmosphere Diesel Emissions Burden Phase II - Final Report, Report of Investigation Submitted to the Diesel Emissions Evaluation Program (DEEP), Canmet, Canada

[18] Talla, L. Bouvard, V. Grosse, Y. Straif, K. 2012, Carcinogenicity of diesel-engine and gasoline-engine exhausts and some Nitroarènes, The Lancet Oncology, July

[19] Dual, S., Silverman, D. T., Koutros, S., Blair, A., Sandler, D. P., Lebailly, P. Beane Freeman, L., E. (2016). Use of dieselized farm equipment and incident lung cancer: Findings from the agricultural health study cohort. Environmental Health Perspectives (Online), 124(5), 611. Retrieved from http://search.proquest.com/ docview/1806104391?accountid=17242

[20] Vermeulen, R. Silverman, D.T. Garshick, E. Vlaanderen, J Portengen, L. Steenland, K. 2014. Exposure-Response Estimates for Diesel Engine Exhaust and Lung Cancer Mortality Based on Data from Three Occupational Cohorts", Environmental Health Perspectives, Volume 122 number 2

[21] Villeneuve, P. J. Parent, M.É. Sahni, V. Johnson, K. C., 2011, 'Occupational exposure to diesel and gasoline emissions and lung cancer in Canadian men,' Environmental Research, Volume 111, Issue 5, July 2011, Pages 727-735, ISSN 0013-9351 
[22] Whitby K. T and Cantrell B. K. 1976. Atmospheric aerosols: Characteristics and measurement. In Proceedings of the International Conference on Environmental Sensing and Assessment (ICESA), Institute of Electrical and Electronic Engineers (IEEE). IEEE \#75-CH 1004-1, ICESA paper 29-1 (6pp). Washington, DC: IEEE.

[23] World Health Organization(WHO). 2012.. Diesel Engine Exhaust Carcinogenic. IARC Press Release. 